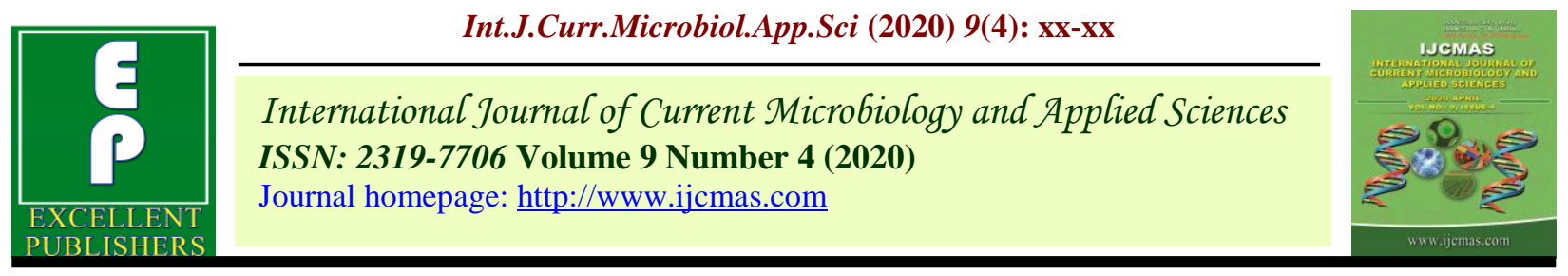

Original Research Article

https://doi.org/10.20546/ijcmas.2020.904.115

\title{
Location Assessment of Wilt Causing Pathogen Fusarium oxysporum F. Sp. ciceri in Seeds of Chickpea Varieties
}

\author{
Vikram D. Singh $^{1 *}$, Shyam Singh ${ }^{1}$ and R. K. Gangwar ${ }^{2}$ \\ ${ }^{1}$ Department. of Botany, Meerut College Meerut, Uttar Pradesh, India \\ ${ }^{2}$ Main Rice Research Station, Ananad Agriculture University, Gujarat, India \\ *Corresponding author
}

\begin{tabular}{|l|}
\hline Ke y w o r d s \\
Gram, Resistant, \\
Susceptible, Wilt \\
\hline Article Info \\
\hline $\begin{array}{l}\text { Accepted: } \\
10 \text { March } 2020 \\
\text { Available Online: } \\
10 \text { April } 2020\end{array}$ \\
\hline
\end{tabular}

\section{A B S T R A C T}

This crop (chickpea) is subjected to attack by a number of fungal, viral, bacterial and nematode diseases. Inadequate information is available on the Fusarium wilt of gram as regards to seed-borne nature. In present studies total ten varieties seed, in which five susceptible viz., Radhey, JG-62, Pusa-372, Pusa-329 and ICP-1454 and five resistant viz., Avarodhi, KWR-108, KGD-1168, JG-315 and JG-130 (resistant to disease under field condition) were taken. The test pathogen was detected in the all-susceptible varieties of chickpea seeds ranging from 11-26 $\%$.The average recovery percentage from sodium hypochlorite $(\mathrm{NaOCl})$ and mercuric chloride $\left(\mathrm{HgCl}_{2}\right)$ pre-treated seeds were 13.6 and 5.6 percent. These were some differences in the recovery of seed infection in the varieties. It was found minimum in Pusa-329 (11\%) and maximum in JG-62(26\%) followed by ICP-1454 (24\%), Radhey (16\%) and Pusa-372 (14\%) respectively. Test pathogen was not presented in resistant varieties seeds except only in Avarodhi (5\%) variety. Other remaining resistant varieties like KWR-108, KGD-1168, JG-315 and JG-130 did not carry seed infection of the test pathogen.

\section{Introduction}

Gram is a type of plant of pulse crops which is having the seed in a pod, that's containing two or three peas in a single pod. Gram belong to the order Fabales and family Fabaceae is an herbaceous annual, having branching close to the ground with semi-erect to semi-spreading in habit. In India chickpea (Cicer arietinum L.) variously known as
Gram or Bengal gram. Manly two types of chickpea are grown, first one is brown seeded type called as "Desi" and second one is white seeded called as a "Kabuli". Occurrence of chickpea wilt was first described in India by (Butler, 1918). According to (Vishwadhar and Gurha, 1998) chickpea is the third most important pulse crop in the worlds after dry beans (Phaseolus vulgaris L.) and dry peas (Pisum sativum L.). It has white flower with 
blue, pink or violet veins. Its center of origin is considered to be in the tract lying between Caucasus and Himalayas from where it has spread to different countries including India.

Pulse crops play an important role in Indian agriculture, besides being rich in protein. Sprouted seeds are recommended for breakfast. Exudation of leaves locally called "Amb" contains malice and oxalic acids, which possess medicinal value for bronchitis, cholera, constipation, diarrhea, digestive disorders, snake-bites, warts and blood purification. It's also prescribed for intestinal disorders.

The availability of pulses per capita is $27 \mathrm{gm}$. /day. In India, chickpea is sow in the month of mid-October to mid-November in un-irrigated areas and in the month of December for recommended under irrigated areas. It's harvested after 100 to 150 days as according to the varieties maturity characters.

In India total area under chickpea cultivation is 9.90 million hectares with annual production of 9.60 million tones and average productivity of chickpea is $960 \mathrm{~kg} / \mathrm{ha}$. Whereas the total area and production of chickpea in Uttar Pradesh is 4.45 lakh hectare and 2.98 lakh tones, respectively, having productivity of $669 \mathrm{~kg} / \mathrm{ha}$ (Anonymous, 2016).

Chickpea seeds are taken fresh as green vegetables or roasted as snack food, sweet and condiments by human. In animal feed is another use of chickpea in many developing countries. Its husks, green or dried stems and leaves are used for cattle feed; chickpea whole seeds may be milled directly for feed.

Leaves are said to yield an indigo like dye. In human it's also consumed as whole seed in the form of fried and boiled for to full fill the protein deficiency. Fresh and disease free young plant and its green pods are eaten like spinach or are used as vegetable. The grains are also used as vegetable (Chhole). Seeds are ground and the flour can be used as soup, dhal and for making to the bread, prepared with pepper, salt and lemon it is served as a side dish.

Gram flour is mixed with wheat flour to improve the protein content of wheat flour and it's used in making chapatti (Roti). The flour of dehusked gram called 'Besan' which is widely used for making to the Pakodas, Kadhi, Namkeens and several snacks foods. A little proportion of canned chickpea is also used in Turkey and Latin America to produce fermented food.

Pulses are grown 60 per cent in Rabi and 40 per cent in Kharif. One hundred-gram chickpea seeds contain about 9.8 per cent Moisture, 21.1 g Protein, 5.3 g Fat, $61.0 \mathrm{~g}$ Carbohydrates and $3.9 \mathrm{~g}$ Fiber in addition to Vitamins. They sustain the productivity of the cropping system. Their ability to use atmospheric nitrogen through Biological nitrogen fixation (BNF) is economically sounder and environmentally acceptable.

According to (Erwin, 1958) were reported that the foliage of $F$. oxysporum f. sp. ciceri infected plant turns yellow before wilting and the xylem tissue shows light brown discoloration. According to (Haware et al., 1978) found the wilt fungus in the hilum of chickpea seeds.

It was eradicated by seed treatment with Benlate T (Benomyl + Thiram). According to (Haware and Nene, 1980) they were reported that the chickpea wilt causes complete loss ingrain yield if the disease occurs in the vegetative and reproductive stages of the crop and when seed harvested from wilted plants they were lighter than those collect from healthy chickpea plants. 
According to (Haware et al., 1982) they were showed the fungus to bein the hilum of the infected seed in the form of chlamydospores like structures. According to (Pande et al., 2007) it was founded that infected seeds play an important role in the long-distance dispersal of the pathogen and in its introduction into $F$. oxysporum f. sp. ciceri free soils and geographic areas also.

According to (Singh et al., 2010) they were reported that. Fusarium wilt is one of the major diseases of chickpea and they were found that at national level the yield losses up to the tune of 60 per cent.

According to the (Arunodhyan et al., 2014) they was stated that $F$. oxysporum f. sp. Cicero infects chickpea at seedling as well as at flowering and podforming stage, with more incidence at flowering andpod filling stage if the crop is subjected to sudden temperature rise and water stress.

It is more prevalent in lower latitudes (0$30^{\circ} \mathrm{N}$ ) where growing season is relatively dryer and warmer than in the higher latitudes $\left(30-40^{\circ} \mathrm{N}\right)$. According to (Trivedi and Rathi, 2016)they was reported that $F$. oxysporum f. sp. ciceri is the seed borne in nature and found that its mycelium was presented in the hilum region of the infected seeds which was collected from wilt affected plants of chickpea when it was isolated on Potato dextrose agar (PDA).

According to (Suman Patra and MohanKumar Biswas, 2017) they was reported that F.oxysporum f. sp. ciceri is the most destructive and widespread fungal disease of chickpea. It has drastic effect on yield causing cent per cent loss under favorable conditions.

This crop (chickpea) is subjected to attack by a number of fungal, viral, bacterial and nematode diseases. Inadequate information is available on the Fusarium wilt of gram as regards to seed borne nature. Out of these maladies, wilt causes considerable loss to gram in India every year.

It is a complex problem and various pathogens as well as physiological factors are implicated to cause wilt of gram, which lead to variation in disease syndrome, although often there is overlapping of symptoms.

However, the typical vascular wilt in chickpea caused by $F$. oxysporum f. sp. ciceri is the outstanding problem in Uttar Pradesh.

\section{Test pathogen}

Fusarium oxysporum is a saprophyte or a heterotroph in nature they can easily obtain their food from organic matter through decomposing method. They are filamentous and belong to the Class Ascomycetes and Family Hypocreaceae. They are typically produce microconidia and macroconidia aswell as mycelia and chlamydospores that serve as propagules in infected chickpea plant.

Test pathogen lifecycle can be divided into three stages like dormant, parasitic and saprophytic stages. $F$. oxysporum has many Formae speciales (special forms) that exist as plant pathogens, which are clearly differentiated according to host range, causing storage, root, stem and fruit rot, as well as vascular wilt.

Healthy plant is infected by F. oxysporum when that pathogen is already presented in that soil where that plant was grows. Test pathogen proceeds to infect the host through its sporangial germ tube or through mycelium by invading the plants roots. If any wound are found in the roots or at the formation point of lateral roots the fungus were inserted into this. 
Once inside the plant, it travels from root to the stem several inches above in the ground level. Some species of test pathogen can be taking much height after getting the entry in plant by virulence condition.

As its growth, the mycelium branched and produces microconidia, which are carried upward within the vessel by way of the plants sap stream. They are easily isolated from tap root, lateral roots and collar region, main stem, lateral branches and pod hulls also according to (Mahendra Pal et al., 1998).

\section{Wilt}

Chickpea wilt caused by $F$. oxysporum f. sp. ciceri. Its symptoms can be seen on the seedlings as well as at the maturity stage of the diseased plants. Its starts out looking like vein clearing on the younger leaves and drooping of the older lower leaves, followed by stunting and pale yellowing of the lower plant leaves and ultimately dry up. Yellow dry leaves are defoliated; marginal necrosis of infected leaves is also seen.

Reddish to black discoloration of the xylem vessels are seen inside the infected plant near by ground stem as a line or dots in cross section. Roots of wilted plants turn black and decompose in later stage. Sometime if stem are grown under much wet condition than white, pink or orange fungal growth are seen outside of the affected stems, to root or stem decay. After that infected plant has dead.

\section{Identification of test pathogen}

To find out the presence of test pathogen in seeds from all ten varieties of chickpea was done under the Stereo binocular microscope (SBM). It's based on the measurements of different morphological structures. Observations of the following morphological characters of the fungus were noted.

\section{Colony characteristic}

Colonies were white initially, radiating are early stage of growth with wine-red pigmentation visible from the bottom side of the without too disturbing of seeds place. In some strains discrete orange colour are seen due to presence of some mass of hyphae at middle point of the growth.

Its plays the role of a silent assassin the pathogenic strains of the fungus can be survive for up to 20 years as in dormant or unfavorable condition.

\section{Mycelium characteristics}

Color, branching pattern and width of the hyphae was studied during this study. Mycelium seen profusely branched, creeping, hyaline, cylindrical, septate and measuring $3.20-4.6 \mu \mathrm{m}$ in width.

\section{Sporodochia}

The test fungus produces white to light orange sporodochia on PDA. When conidiophoresare often clustered to form sporodochia and produce large pasty masses of spores. Three types of asexual spores are found.

\section{Microconidia}

The microconidia were hyaline, oval to cylindrical in shape and straight to slightly curved and measuring $2.5-3.5 \times 5-11 \mu \mathrm{m}$ in size. They are smaller than macroconidia in size having only one or two celled and they are frequently produced by the fungus under any conditions.

\section{Macroconidia}

The macroconidia were spare and produces on the branched conidiophores. They were hyaline, three to several celled, fusiform to 
sickle shaped (curved toward of the ends), mostly with an elongated apical cell and pedicellate basal cell. Its measuring is $3.0-$ $4.5 \times 20-55 \mu \mathrm{m}$ in size noted.

\section{Chlamydospores}

The chlamydospores were usually intercalary and one produced singly or in pairs. They were globes to sub-globes, thick-walled and smooth surfaced spores. Chlamydospores are seen like swelling is often on the hyphae and measuring 7.0- 8 x $3.5-5.0 \mu \mathrm{m}$ in size. They can remain dormant in soil for long periods and infect other host under favorable condition.

\section{Materials and Methods}

In present studies, total ten varieties seed, in which five susceptible viz. Radhey, JG-62, ICP-1454, Pusa-372 and Pusa-329 and five resistant viz., Avarodhi, KWR-108, KGD1168, JG-315 and JG-130 (resistant to wilt disease under field condition) were taken from Indian institute of pulses research (IIPR) Kanpur (UttarPradesh) India and pulse research farm of Economic botany legume (EBL) section of Chandra Shekhar Azad University of Agricultural and Technology (CSAUA\&T), Kanpur (Uttar Pradesh) India.

All seeds brought to the laboratory of department of botany, Meerut Collage Meerut (UP) for the examined of the location of Wilt causing pathogen Fusarium oxysporum f. sp. ciceriin seeds. Two methods was used first one is Standard blotter method (SBM) and second one is Agar plat method (APM). The study of seed infection, pattern and growth habit of test pathogen was examined under invitro conditions.

All fungus colonies were separately observed on seed in-situ through using of Standard blotter method (SBM) according to proposed by International seed testing association (ISTA, 1999).

According to suggestion of (Neergaard, 1979) these observations were also recordedby use to agar plate method for the re-confirmation of those results, which is obtained during standard blotter method test. Growth habit of test pathogen in-situ method such technique was follow as given below.

\section{Standard blotter method (SBM)}

Standard blotter method was used for the detection of seed borne fungi of chickpea. Three hundred seeds of each variety was randomly select from properly homogenize samples, each sample was mixed and divide by precision divider (Gamet type) and then each sample further divided into three lots, each lot contain one hundred seeds.

First lot of one hundred seed remains as untreated (control). Second lot was pre-treat with $1 \%$ Sodium hypochlorite $(\mathrm{NaOCl})$ for 10 minutes and third lot pre-treat with $0.1 \%$ Mercuricchloride $\left(\mathrm{HgCl}_{2}\right)$ solution for 1 minute.

This experiment was conducted during in the yearof 2019-2020 in a Completely randomized design (CRD) with ten replications were use from each lot untreated as control \&pretreated with $(\mathrm{NaOCl}$ and $\mathrm{HgCl}_{2}$ ) of each ten variety of chickpea. Each replication was contained 10seeds.Selected 10 seeds were arranged as 9 seeds in the outer ring and 1 seed in the center place on three pre-soaked moist layers of sterilize blotter paper from sterile distill water; kept in $90 \mathrm{~mm}$ diameter polypropylene/glass petri-plates.

These plates were incubated at $25 \pm 2{ }^{\circ} \mathrm{C}$ under alternating cycle of 12 hours Near Ultra Violet (NUV) light and 12 hour darkness for seven days. On eighth day, the seed was 
examined under Stereo-binocular microscope (SBM) at the range on $(6.4 \times 40 \mathrm{x})$ for the presence of $F$. oxysporum f.sp. ciceri. The numbers of seed bearing colonies of the test pathogen was count, record and interpret as percent infection of the test pathogen.

\section{Agar plate method (APM)}

Agar plate method is preferred mostly in plant pathological studies as it provides nutrients rich substrate for the development of fungal mycelial growth and sporulation of the pathogen on seed, its use mostly for slow growing fungi. In this method, Potato dextrose agar medium was used in the place of blotter paper. One capsule of chloramphenicol $500 \mathrm{mg}$ was added in each flask containing $200 \mathrm{ml}$ of PDA medium before pouring in petri-plates in order to check the any bacterial contamination. One hundred fifty seeds were randomly select from properly homogenize samples; each sample (variety) was further divided, with help of precision divider (Gamet type) into three lots, each lots contain 50 seeds.

First lot of 50 seed remains as untreated (control). Second lot was pre-treat with $1 \%$ Sodium hypochlorite $(\mathrm{NaOCl})$ for 10 minutes and third lot pre-treat with $0.1 \%$ Mercuric chloride $\left(\mathrm{HgCl}_{2}\right)$ solution for 1 minute. This experiment was conducted during in the year of 2019-2020;in a completely randomized design (CRD) with ten replications was used from each lot (Untreated \& Pretreated with $\mathrm{NaOCl}$ and $\mathrm{HgCl}_{2}$ ) of each variety.

Each replication was contained 5 seeds. Selected 5 seeds were arranged as 4 seeds in the outer ring and 1 seed in the center place on $90 \mathrm{~mm}$ PDA petri plate. Then the plates were incubated for 7 days and next day, the growth of the fungus on seed was examined by necked eye and for specific identification of the test pathogen, Stereo-binocular microscope and Compound microscopes (CM) were use. The numbers of seed bearing colonies of $F$. oxysporum f. sp. ciceri were counts, records and interpret in per cent infection of thetest pathogen.

\section{Results and Discussion}

The data on per cent seeds infection of Fusarium oxysporum f. sp. ciceri in different chickpea cultivars in Standard blotter method and Agar plate methods are presented in Table 1. The results in Table 1 show that the average recovery percentage from Sodium hypochlorite $(\mathrm{NaOCl})$ and Mercuric chloride $(\mathrm{HgCl})$ pretreated seeds were13.6 and 5.6 percent.

These were some deference's in the recovery of seed infection in the varieties. It was founded minimum in Pusa-329 (11\%) and maximum in JG-62 (26\%) followed by ICP 1454 (24\%), Radhey (16\%) and Pusa-372 (14\%), respectively. Test pathogen (Fusarium oxysporum f. sp.ciceri) was not founded in the resistant varieties, except only Avarodhi (5\%) variety. Other remaining resistant varieties viz., KWR-108, KGD-1168, JG-315 and JG130 did not carry seed infection of the test pathogen.

Standard blotter methods had an edge over Agar plate method (Fig. 1). So far, as the detection of the pathogen was concerned. In present study, out of ten seed samples, collated from susceptible $\&$ resistant cultivars was tested for the presence of the pathogen on seed by using standard blotter method\& agar plate method, the test pathogen ( $F$. oxysporum f. sp. ciceri) was detected in the all susceptible varieties of chickpea ranging from 11-26 per cent. It's also present in only one resistant variety namely Avarodhi except others varieties, during in this test. 
Table.1 Per cent seed infection of $F$. oxysporum f. sp. ciceri in chickpea cultivars in Standard blotter method and Agar plate method

\begin{tabular}{|c|c|c|c|c|c|c|c|}
\hline \multirow[t]{3}{*}{ Sl. No. } & \multirow[t]{3}{*}{ Sample } & \multicolumn{3}{|c|}{ Standard blotter method } & \multicolumn{3}{|c|}{ Agar plate method } \\
\hline & & \multirow[t]{2}{*}{ Untreated } & \multicolumn{2}{|c|}{ Pre-treatment with } & \multirow[t]{2}{*}{ Untreated } & \multicolumn{2}{|c|}{ Pre-treatment with } \\
\hline & & & $\mathrm{NaOCl}$ & $\mathrm{HgCl}_{2}$ & & $\mathrm{NaOCl}$ & $\mathrm{HgCl}_{2}$ \\
\hline \multicolumn{8}{|c|}{ Susceptible cultivars } \\
\hline 1. & JG-62 & 26 & 19 & 8 & 24 & 17 & 7 \\
\hline 2. & ICP-1454 & 24 & 16 & 7 & 20 & 13 & 5 \\
\hline 3. & Radhey & 16 & 13 & 5 & 13 & 8 & 5 \\
\hline 4. & Pusa-372 & 14 & 11 & 5 & 12 & 9 & 4 \\
\hline \multirow[t]{2}{*}{5.} & Pusa-329 & 11 & 9 & 3 & 11 & 7 & 2 \\
\hline & Average & 18.2 & 13.6 & 5.6 & 16.0 & 11.4 & 4.6 \\
\hline \multicolumn{8}{|c|}{ Resistant cultivars } \\
\hline 6. & Avarodhi & 5 & 2 & 0 & 3 & 0 & 0 \\
\hline 7. & $\begin{array}{c}\text { KWR- } \\
108\end{array}$ & 0 & 0 & 0 & 0 & 0 & 0 \\
\hline 8. & $\begin{array}{c}\text { KGD- } \\
1168\end{array}$ & 0 & 0 & 0 & 0 & 0 & 0 \\
\hline 9. & JG-315 & 0 & 0 & 0 & 0 & 0 & 0 \\
\hline \multirow[t]{2}{*}{10.} & JG-130 & 0 & 0 & 0 & 0 & 0 & 0 \\
\hline & Average & 1.0 & 0.4 & 0.0 & 0.6 & 0.0 & 0.0 \\
\hline
\end{tabular}

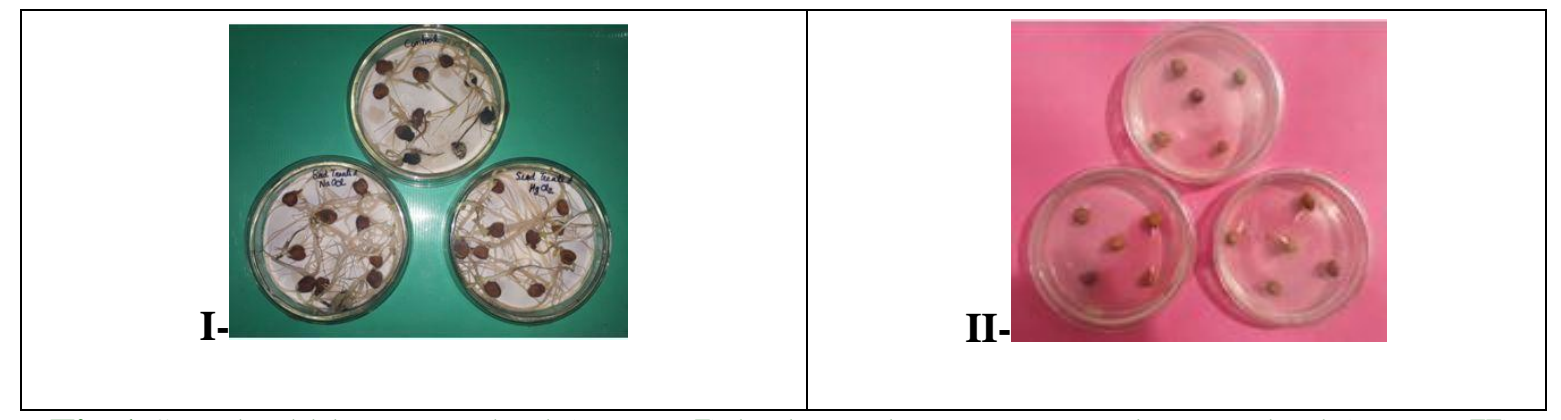

Fig.1 Standard blotter method (Image-I) had an edge over agar plate method (Image-II)

The pre-treatment of the seeds of all ten varieties with the Sodium hypochlorite and Mercuric chloride, reduced the recovery of the test pathogen from the infected seeds of chickpea cultivars. Total ten varieties seed, in which five susceptible viz. Radhey, JG-62, ICP-1454, Pusa-372 and Pusa-329 and five resistant viz., Avarodhi, KWR-108, KGD1168, JG-315 and JG-130 were taken. Presence of the test pathogen in the seeds of all ten varieties of chickpea was done under the Stereo binocular microscope (SBM). It's based on the measurements of different morphological structures. Observations of the following morphological characters of the fungus were noted.

All fungus colonies were separately observed on seed in-situ through using of Standard blotter method (SBM) according to proposed by International seed testing association (ISTA, 1999). According to suggestion of 
(Neergaard, 1979) these observations were also recorded by use to agar plate method for there-confirmation of those results, which is obtained during standard blotter method test.The average recovery percentage from Sodium hypochlorite $(\mathrm{NaOCl})$ and Mercuric chloride $(\mathrm{HgCl} 2)$ pretreated seeds were 13.6 and 5.6 percent it was founded minimum in Pusa-329 (11\%) and maximum in JG-62 (26\%).

Test pathogen (Fusarium oxysporum f. sp. ciceri) was not presented in resistant varieties, exceptvariety Avarodhi (5\%). Other remaining resistant varieties viz., KWR-108, KGD-1168, JG-315 and JG-130 did not carry seed infection of the test pathogen. Standard blotter methods had an edge over Agar plate method in the detection of the pathogen from the infection/ infested seed. Pre-treatment of the seeds with both Sodium hypochlorite $(\mathrm{NaOCl})$ and Mercuric chloride $(\mathrm{HgCl} 2)$ both was capable to reduce therecovery of the test pathogen $(F$. oxysporum $)$ from the seed.

\section{Declarations}

This article does not contain any studies with human participants or animals performed by any of the authors.

\section{References}

Anonymous (2016). Statistical year book 'India-2016' by Ministry of statistics and program Implementation Government of India, pp,156.

Arunodhayam, K., Reddy, N. P. E. and Madhuri, V. (2014). Pathogenicity and management of Fusarium wilt of chickpea. Cicer arietinum L. - A review. Current Biotica. 7(4): 343-358.

Butler, E. J. (1918). Fungi and Disease in Plants. Thacker Spink and Co., Calcutta, India. 547 pp.

Dubey, O. P). ABH Publishing Co., New
Delhi (India). 249.

Erwin, D. C. (1958). Verticillium wilt of Cicer arietinum in southern California. Pl. Disease Reporter.42:1111.

Haware, M. P. and Nene, Y. L. (1980). Influence of wilt at different growth stages on yield loss of chickpea. Tropical Grain Legume Bulletin, 19:3840.

Haware, M. P. and Nene, Y. L. (1982). Races of F. oxysporum f. sp. ciceri. Pl. Dis., 66:809-810.

Haware, M.P., Nene Y.L. and Rajeswari R. (1978). Eradication of $F$. oxysporum $\mathrm{f}$. sp. ciceri transmitted in chickpea seed. Phytopathology, 68: 1364-1367.

International Seed Testing Association (1999). International Rules for Seed Testing. Seed Sci. \& Technol., 27: 332.

Mahendra Pal., Rajeev, K., Upadhyay, K. G., mukherji, B. P., Chomo, A and Dubey, O. P. (1998). Integrated pest and disease management (book).APH Publishing Corporation, New Delhi, India-110-112.

Neergard, P. (1979). Seed Pathology, The Mac Millon Press Ltd. London, Vol. 1: 835.

Pande, S.; Rao, J. N. and Sharma, M. (2007). Establishment of the chickpea wilt pathogen $F$. oxysporum f.sp. ciceri in the soil through seed transmission. $P l$. Path. 23(1): 3-6.

Singh, R. K., AbulHasan and Chaudhary, R. G. (2010). Variability in Fusarium oxysporum f. sp. Cicero causing vascular wilt in chickpea. Archives of Phytopathology and Plant Protection. 43(10): 987-995.

SumanPatra and Mohan Kumar Biswas (2017). Studies on cultural, morphological and pathogenic variability among the isolates of Fusarium oxysporum f. sp. ciceri causing wilt of chickpea. International Journal of Plant, Animal and Environmental. Science. 7(1): 11-16. 
Trivedi, L. and. Rathi, Y. P. S. (2016). Integrated management of seed borne Fusarium oxysporum f. sp.ciceri in chickpea wilt complex. World Journal of Pharmacy and Pharmaceutical
Sciences. 5 (6): 23922402.

VishwaDhar and Gurha, S. N. (1998). Integrated management of chickpea diseases in integrated pest and disease management. (Eds. Rajeev, K., et al.,)

\section{How to cite this article:}

Vikram D. Singh, Shyam Singh and Gangwar, R. K. 2020. Location Assessment of Wilt Causing Pathogen Fusarium Oxysporum F. Sp. Ciceri in Seeds of Chickpea Varieties. Int.J.Curr.Microbiol.App.Sci. 9(04): xx-xx. doi: https://doi.org/10.20546/ijcmas.2020.904.115 